\title{
Klimato kaitos ịtakos Lietuvos vandens ištekliams tyrimai
}

Jūratė Kriaučiūnienė,

Brunonas Gailiušis,

Diana Šarauskienė,

Darius Jakimavičius,

Aldona Jurgelènaité,

Diana Meilutytè-Lukauskienè,

Vytautas Akstinas,

Aldona Tomkevičienė,

Valdas Irbinskas

Lietuvos energetikos institutas,

Hidrologijos laboratorija,

Breslaujos g. 3, LT-44403 Kaunas

El.paštas Jurate.Kriauciuniene@lei.lt
1957 m. prie Hidrologijos laboratorijos vairo stojęs vienas garsiausių Lietuvos hidrologų prof. M. Lasinskas pradejjo vadovauti plataus masto Lietuvos vandens telkinių tyrimams. Atlikta daug ịvairaus pobūdžio studijų, publikuotos svarbios monografijos. Pastaraisiais dešimtmečiais laboratorijos tyrimų objektai išlieka tie patys, tačiau keičiasi tyrimu problematika, turima daugiau hidrologinių duomenų ir taikomi modernūs tyrimo metodai. Straipsnyje pateiktas Lietuvos energetikos instituto Hidrologijos laboratorijos indèlis hidrologijos mokslo raidai, aprašyti reikšmingiausi pastarojo dešimtmečio darbai, susiję su klimato kaitos ịtaka Lietuvos vandens telkinių (upių ir Kuršių marių) ištekliams. Taip pat ištirti Lietuvos upių nuotekio ir Kuršių marių balanso elementų pokyčiai praeityje, statistiniais metodais nustatyti upių nuotekkio ir jo ekstremaliu reikšmių pokyčiai, pateikta Nemuno baseino, apimančio 75 \% Lietuvos teritorijos, upių nuotèkio prognozé, naudojant hidrologini modeli HBV ir 2 globalius klimato modelius (Echam5 ir HadCM3) bei 3 emisijų scenarijus (A2, A1B, B1), ir ịvertinti Kuršių marių vandens balanso pokyčiai XXI a.

Raktažodžiai: klimato kaita, upès, Kuršių marios, statistiniai metodai, hidrologinis modeliavimas

\section{IVADAS}

Kalbant apie hidrologijos mokslo raidą šalyje reikia prisiminti, kaip Lietuvos energetikos instituto (LEI) mokslo darbuotojai prisidejo prie šio proceso. $1957 \mathrm{~m}$. Energetikos ir elektrotechnikos instituto Hidroenergetikos laboratorijoje, kuriai vadovavo prof. M. Lasinskas, pradèti plataus masto Lietuvos vandens telkinių tyrimai. Vadovaujant profesoriui buvo tiriamos upių baseinų nuotèkio skaičiuojamosios charakteristikos (vidutiniai metiniai debitai, maksimalūs ir minimalūs debitai, nuotékio pasiskirstymas per metus), nuotekio formavimosi ir svyravimų charakteristikos, šalies upių tinklo lyginamasis tankis. Hidrologijos labo- ratorijoje atliktas Lietuvos teritorijos hidrologinis rajonavimas, tirti paviršinių ir požeminių vandenų ryšiai, vandens balansas ir jo dinamika. Šių tyrimų pagrindu 1962 m. paskelbta Lietuvos upių kadastro 3-oji dalis (autoriai J. Jablonskis, M. Lasinskas) [1]. Šioje knygoje pateikta daug naujų duomenų apie upių hidrografinius ir hidroenergetinius rodiklius. Pažymint kadastrinių darbų reikšmę sprendžiant mokslo plètros ir vandens ūkio klausimus, autoriams M. Lasinskui, J. Burneikiui, J. Jablonskiui ir J. Macevičiui 1965 m. paskirta Lietuvos valstybinè mokslo ir technikos premija.

Profesoriaus vadovaujama laboratorija tyrè ne tik hidroelektrinių darbo režimus, bet ir hidroakumuliacijos galimybes Lietuvoje. Šiais tyrimais 
nustatytos tinkamiausios vietos hidroakumuliacinèms elektrinèms statyti. Hidrologijos laboratorija aktyviai dalyvavo rengiant rekomendacijas bei renkant vietą branduolinei jègainei. Numačius statyti branduolinę jẻgainę prie Drūkšių ežero, laboratorijai iškilo naujų uždavinių - tirti branduolinès jègainès tvenkinio aušinimo galimybes, prognozuoti, kaip pasikeis ežero vandens balansas, jo šiluminès savybès, kokią ittaką pašildyto vandens telkinys turès aplinkai. Paskutinysis didesnis profesoriaus darbas - $1994 \mathrm{~m}$. išspausdinta bibliografija, kurioje aptarta apie 1300 literatūros šaltinių vien apie Lietuvos upių nuotèkị [2].

Nuo paskutiniųjų Lietuvos upių nuotekkị vertinančių darbų praejjo 30 metų. Per tą laiką sukaupti nauji mokslo duomenys labiau atspindi daugiametę kaitą ir tiksliau aprašo nuotèkio teritorini pasiskirstymą. Ypač svarbu buvo parengti naujus nuotekkio skaičiavimo metodus. Šios krypties darbai paskelbti monografijoje „Lietuvos upès. Hidrografija ir nuotekis" (2001 m.) [3]. Monografijoje nagrinejjami hidrografinio tinklo rodikliai ir struktūra, taip pat apibendrinti 160-ies Lietuvos hidrometrijos stočiu nuotèkio stebèjimų duomenys bei išanalizuotos svarbiausių upių nuotekio hidrologinio režimo charakteristikos. Lietuvos mokslo premijų komitetas 2002 m. Hidrologijos laboratorijos mokslininkams Brunonui Gailiušiui, Jonui Jablonskiui ir Mildai Kovalenkovienei už darbų ciklą „Lietuvos paviršiniai vandens ištekliai, jų kaita ir naudojimas energetikai bei jūrų transportui“ (1980-2001 m.) suteikè Lietuvos mokslo premiją.

Pastaruoju metu dažnai kalbama apie klimato kaitos poveikị hidrologiniams procesams ir vandens ištekliams. Kyla klausimas, ar besikeičiantis klimatas gali turèti ịtakos ekstremaliems hidrologiniams reiškiniams ateityje. Ekstremalūs potvyniai ir sausros yra retai pasikartojantys ịvykiai, ir hidrologai neturi galimybès surinkti pakankamai duomenų apie katastrofas. Norint išvengti ekstremalių hidrologinių reiškinių padaromos žalos ar ją sušvelninti, būtina surinkti visą įmanomą informaciją apie šiuos reiškinius bei juos sukeliančius veiksnius, gautus duomenis susisteminti, išanalizuoti bei panaudoti ekstremalioms situacijoms įvertinti.

Ekstremalių hidrologinių reiškinių (potvynių ir nuosèkio) tyrimai yra aktualūs projektuojant ir eksploatuojant tvenkinius, polderius, tiltus ir pralaidas, taip pat potvynių rizikai valdyti bei planuoti, siekiant išvengti žmonių aukų bei materialinès žalos. Tokių priemonių parengimas Lietuvos upems pagrisstas upių nuotèkio stebejjimais, jų analize bei skaitmeniniu modeliavimu. Hidrologijos laboratorijoje išanalizuotos Lietuvos upių ekstremalių hidrologinių reiškinių formavimosi sąlygos ir įvertinta daugiametè upių nuotékio ekstremalių parametrų kaita, atlikta šių reiškinių prognoze pagal naujausius klimato kaitos scenarijus XXI a. Šiandien vienas svarbiausių uždavinių, susijusių su ekstremalių hidrologinių reiškinių keliamais pavojais Lietuvoje, yra saugi hidrotechninių statinių eksploatacija bei naujų statinių projektavimas atsižvelgiant $\mathfrak{i}$ besikeičiančias klimato sąlygas ir kintantị upių vandeningumą, siekiant visiškai bei visapusiškai ịvertinti pavojų ir užtikrinti pavojingo objekto saugą [4].

Pastarąji dešimtmetị Hidrologijos laboratorijoje buvo sukurta originali nuotekio kaitos, potvynių ir poplūdžių bei nuosèkio vertinimo per daugiameti laikotarpi metodika (statistiniai metodai). Upių nuotèkio kaita ir Kuršių marių balanso elementai (krituliai, išgaravimas, upių prietaka, vandens apykaita tarp marių ir jūros) prognozuoti taikant klimato kaitos modelius ir hidrologini modeliavimą. Taip pat sudaryta tyrimams reikalinga hidrologinių ir meteorologinių duomenų bazè. Hidrologijos laboratorijoje išanalizuoti upių nuotèkio bei jo ekstremalių reikšmių (potvynių ir sausmečio) pokyčiai klimato kaitos fone, ivvertinta potvynių ir sausmečio pavojaus rizika įvairiose aplinkose ir veiklose (gamtos apsauga, vandens išteklių naudojimas, energetika). Išanalizuoti tikètini Kuršių marių vandens balanso pokyčiai XXI a. Pagrindiniai atliktų darbų rezultatai paskelbti aukšto mokslinio lygio leidiniuose, dažnai kartu su užsienio ir kitų Lietuvos mokslo istaigų kolegomis [5-12].

Straipsnio tikslas - apžvelgti pastaraisiais metais vykdytus svarbiausius LEI Hidrologijos laboratorijos darbus, susijusius su besikeičiančio klimato įtaka Lietuvos vandens ištekliams - upių nuotekkio režimui bei Kuršių marių balansui.

\section{METODIKA}

Statistiniais metodais nustatyti jau įvykę upių nuotèkio pokyčiai, ypač atkreipiant dèmesị $\mathfrak{i}$ hidrologinius ekstremumus (potvynių ir nuosékio 
debitus). Kuršių marių vandens balansas apskaičiuotas vandens balanso metodu. Prognozuotas Nemuno baseino, apimančio 75 \% Lietuvos teritorijos, upių nuotèkis naudojant hidrologini modeli ir 2 globalius klimato modelius bei 3 emisijų scenarijus. Ivertinti Kuršiu mariu vandens balanso pokyčiai XXI a. pagal 3 jūros lygio ir jau minètus klimato kaitos scenarijus.

\section{Statistiniai upių nuotèkio kaitos analizès metodai}

Trendų analizè. Trendas yra kryptingas tiriamojo rodiklio pokytis. Upių nuotèkio bei jo ekstremalių reikšmių trendai analizuoti naudojant labai plačiai taikomą statistinès analizės neparametrinị Mann-Kendall testą. Šis testas taikomas tiek tiesiniams, tiek netiesiniams trendams aprašyti. Jit rekomenduoja Pasaulio meteorologijos organizacija [13] meteorologinių ar hidrologinių charakteristikų kaitos trendams iqvertinti. Šiuo metodu nustatomi teigiami arba neigiami tiriamosios charakteristikos trendai (30\% patikimumo lygmuo) ir reikšmingi teigiami arba neigiami trendai (5\% patikimumo lygmuo), kurie pateikiami diagramose, o nustatytų trendų skaičius sumuojamas ir išreiškiamas procentais nuo tiriamụjų stočiu skaičiaus. 5 ir $30 \%$ patikimumo lygmens trendai pavaizduoti kartografinèse schemose, jos suteikia galimybę vertinti nustatytų trendų pasiskirstymo teritorijoje dèsningumus. Toks rezultatų pateikimas ypač svarbus lyginant įvairiose šalyse atliktus tyrimus. Taikant trendų analizę, ivvertinta Lietuvos upių ekstremalių hidrologinių reiškinių daugiametè kaita.

Tikimybiniai ekstremalių hidrologinių reiškinių dažnumo vertinimo metodai. Nuotẻkio ekstremalių reiškinių rizikai vertinti taikyta dažnumo analizè, kurios tikslas - susieti tiriamųjų įvykių dydị su jų pasikartojimo dažnumu naudojant tikimybinius skirstinius. Pasirinktos tikimybès potvyniams upése prognozuoti naudoti metiniai maksimalių debitų stebejjimo duomenys, skaičiuojant tokius statistinius rodiklius kaip vidurkiai, standartiniai nuokrypiai, asimetrija ir pasikartojimo intervalai. Prognozuojant nuosẻkio minimalius debitus naudoti metiniai minimalių debitų stebèjimo duomenys. Vèliau šie statistiniai duomenys buvo naudojami dažnumo skirstiniams sudaryti. Projektuojant hidrotechninius statinius, atsižvelgiant $\mathfrak{i}$ statinio klasę, yra naudojamos atitinkamų tikimybių hidrologinių charakteristikų projektinès reikšmès. Šias reikšmes reikètų kuo tiksliau ịvertinti, nes apskaičiavus mažesnius maksimalius debitus padidètu hidrotechninių statinių griūties rizika, o pervertinus debitus - išaugtų statybos kaina. Upių ekstremalių nuotèkio reikšmių tikimybinei analizei buvo pasirinkti trijų parametrų Gama (Pirsono III tipo) (G3), logaritminis Pirsono III tipo (LP3), Gumbelio (EV1), Veibulo (W2) ir apibendrintujų ekstremalių reikšmių (GEV) tikimybiniai skirstiniai. Parametrams vertinti naudoti momentų, L-momentų bei didžiausio tikètinumo metodai. Tinkamiausi skirstiniai atrinkti Kolmogorovo-Smirnovo ir Andersono-Darlingo testų dèka. Tyrimui naudota EasyFit (sukurta MathWave Technologies) programa.

\section{Nemuno hidrologinio modelio sudarymas ir upių nuotėkio modeliavimas}

Lietuvos upių nuotèis prognozuotas pagal ECHAM5 (Makso Planko meteorologijos institutas) ir HadCM3 (Jungtinès Karalystès Hadley klimato tyrimų ir prognozių centras) globalių klimato kaitos modelių išvesties duomenis ir tris šiltnamio reiškinị sukeliančių dujų emisijų scenarijus. Modeliuojant dažniausiai naudojami trys emisijų scenarijai: pesimistiškiausias (A2), vidutinis ir labiausiai tikètinas (A1B) bei švelniausias (B1). Upių nuotekkiui prognozuoti taikytas Švedijos meteorologijos ir hidrologijos institute sukurtas HBV modelis. Šiuo modeliu skaičiuojamas bendras upių baseino vandens balansas. Pagrindinè HBV lygtis yra [14]:

$$
P-E-Q=\frac{d}{d t}[S P+S M+U Z+L Z+V]
$$

čia: $P$ - krituliai, $E$ - evapotranspiracija, $Q$ - nuotèkis, $S P$ - vandens atsargos sniege, $S M$ - dirvos drègmé, $U Z$ - gruntinis vanduo, $L Z$ - požeminis vanduo, $V$-vandens talpyklų tūris.

Upių nuotèkis skaičiuojamas 3 etapais: 1) žemès paviršių pasiekiančių kritulių kiekio nustatymas; 2) šlaitų nuotèkio apskaičiavimas; 3 ) vagų nuotèkio bei nuotèkio transformacijos îvertinimas.

Kuriamojo hidrologinio modelio tikslas - sumodeliuoti Nemuno baseino nuotèki 2011$2100 \mathrm{~m}$. laikotarpiui, todèl visų pirma reikia 
apibrèžti modeliuojamojo baseino ir pabaseinių teritoriją apibūdinančią geografinę informaciją: baseinų bei pabaseiniuose esančių miškų ir ežerų plotus, taip pat vidutinius baseinų aukščius virš jūros lygio.

Kuriant Nemuno baseino hidrologinị modelị buvo surinkta informacija apie paros vidutinius debitus (hidrologiniai duomenys) iš Nemuno baseine esančių vandens matavimo stočių (VMS), paros kritulių sumą bei vidutinę paros oro temperatūrą (meteorologiniai duomenys) iš meteorologinių stočių (MS). Kuriant Nemuno modelį buvo panaudoti debitai iš 10 VMS bei oro temperatūra ir krituliai iš $14 \mathrm{MS}$.

Hidrologiniam modeliui kalibruoti naudojama 16 parametrų, kurie priklauso nuo vietinių sąlygų ir yra skirtingi atskiroms geografinèms sritims. Nuo teisingo kalibravimo parametru parinkimo priklauso rezultatų patikimumas. Modeliui sudaryti panaudota 1961-1990 m. laikotarpio, kuris pagal PMO yra laikomas klimato norma, hidrometeorologine informacija [15]. Modeliui kalibruoti pasirinktas 1961-1975 m. laikotarpis, o validuoti - 1976-1990 m. laikotarpis. Kalibruojant Nemuno hidrologinị modelị vertinama, kaip išmatuotas debitas sutampa su apskaičiuotu debitu keičiant kalibruojamų parametrų reikšmes. Atlikus kalibravimą, vizualiai palyginti sumodeliuoto ir apskaičiuoto nuotékio hidrografai (1 pav.). Tarp sumodeliuoto ir apskaičiuoto nuotèkio kalibracijos metu koreliacijos koeficientas yra $\mathrm{R}=0,88$. Naudojant tuos pačius (jau sukalibruotus) parametrus, modeliuojama 1976-1990 m. Nemuno prietaka. Atli- kus modelio validaciją, sumodeliuotas Nemuno nuotekis žiotyse palyginamas su apskaičiuotu $(\mathrm{R}=0,84)$. Atsižvelgiant $\mathfrak{i}$ gautus modelio kalibravimo bei validacijos rezultatus galima teigti, kad modelis visiškai paruoštas prognozuoti $\mathrm{Ne}$ muno prietaką XXI a. pagal ịvairius klimato kaitos scenarijus.

\section{Kuršių marių vandens balanso skaičiavimo metodikos sudarymas}

Kuršių marių vandens balansas apskaičiuotas pagal lygti:

$$
\left(Q_{U}+P-Z\right)+\left(Q_{J}-Q_{M}\right)= \pm \Delta V
$$

čia: $Q_{U}$ - upių prietaka ị Kuršių marias $\left(\mathrm{km}^{3}\right)$, $P$ - krituliai ant Kuršių marių paviršiaus $\left(\mathrm{km}^{3}\right)$, $Z$ - išgaravimas iš Kuršių marių $\left(\mathrm{km}^{3}\right), Q_{I}$ - prietaka iš Baltijos jūros $\mathfrak{i}$ Kuršių marias $\left(\mathrm{km}^{3}\right)$, $Q_{M}$ - nuotèkis iš Kuršių marių ’ Baltijos jūrą $\left(\mathrm{km}^{3}\right), \Delta V-$ Kuršių marių tūrio pokytis $\left(\mathrm{km}^{3}\right)$.

Upių prietaka skaičiuota paros žingsniu. Jai suskaičiuoti sukurta metodika naudojant tiesioginius VMS duomenis ir analogijos metodus, skirtus nustatyti nuotèkiui iš tų baseino dalių, kuriose nuotèkis nematuojamas. Debitas iš stočių, kuriose matuojami debitai, perskaičiuojamas upės žiotims ir iš žiočių perskaičiuojamas marioms (įvertinus atitekejjimo laiką). Upių baseinų plotai bei reikiami hidromoduliai paimti iš monografijos [3].

Krituliai ir išgaravimas. 1961-2007 m. Lietuvos teritorijoje krituliai matuoti Klaipedos, Nidos ir Ventes MS. Suminis kritulių kiekis skaičiuotas mènesio laikotarpiui taikant Tyseno poligonų

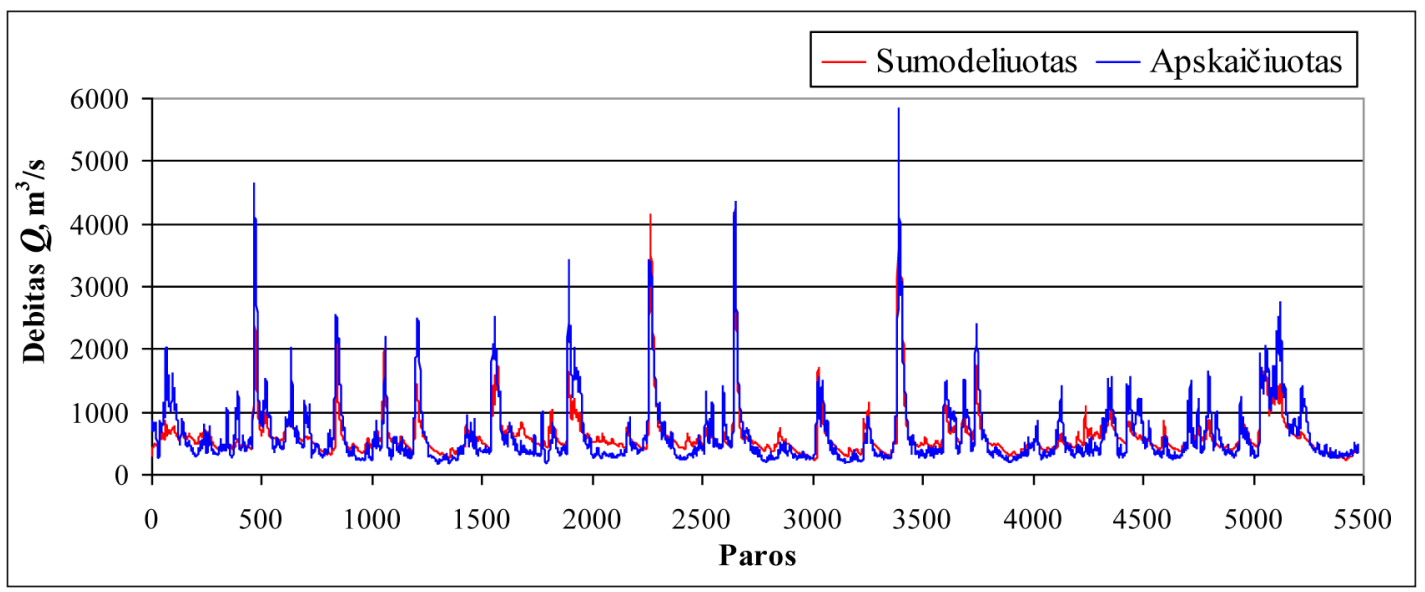

1 pav. Sumodeliuoto ir apskaičiuoto debito ties Nemuno žiotimis palyginimas modelio kalibravimo laikotarpiu (1961-1975 m.) 
metodą [16], kuriuo ịvertinta kiekvienai stočiai priskirta teritorija. Tiesioginių išgaravimo duomenų nuo marių vandens paviršiaus nèra, todèl jis skaičiuojamas pagal empirines formules, pagrịstas hidrometeorologiniais elementais.

Túrio pokytis. Norint apskaičiuoti kiekvienos paros marių vandens tūrio pokytí, reikia turèti kiekvienos paros vidutinį marių vandens lygi bei upių prietaką. Marių vandens lygių svyravimams ìvertinti pasirinkta Juodkrantės hidrologiné stotis. Turèdami vidutini marių vandens lygi, apskaičiuojame lygio pokyti tarp gretimų parų visu tiriamuoju laikotarpiu. Pagal marių vandens paviršiaus ploto priklausomumą nuo vandens lygio [17], naudojant Juodkrantès vandens lygi kaip vidutini marių lygi, apskaičiuotas kiekvienos paros vidutinis marių paviršiaus plotas. Apskaičiavus kiekvienos paros vandens lygio pokyti $(\Delta H)$ ir turint kiekvienos paros marių vandens paviršiaus plotą, galime apskaičiuoti marių tūrio pokytí, išreikštą debitu $\left(\mathrm{m}^{3} / \mathrm{s}\right)$. Turèdami kiekvienos paros marių tūrio pokyčius ir suminę upių prietaką, galime apskaičiuoti apykaitos debitus tarp jūros ir marių, todèl iš tūrio pokyčio atimame suminę upių prietaką. Jei debitas neigiamas, tai vanduo teka iš Kuršių marių ị Baltijos jūrą, o jei teigiamas - priešinga kryptimi.

Vidutinio daugiamečio vandens balanso skaičiavimo tikslumas priklauso nuo kiekvieno nario suskaičiavimo tikslumo. Jeigu gautas balanso nesąryšis yra lygus arba mažesnis už suminę paklaidą $\delta$, galima teigti, kad apskaičiuotas vandens balansas yra pakankamai tikslus.

\section{Kuršių marių vandens balanso prognozès} sudarymo 2011-2040, 2041-2070 ir

2071-2100 m. metodika

Prognozuojamas Kuršių marių vandens balansas skaičiuotas vadovaujantis analogiška metodika bei taikant tą pačią vandens balanso lygtị kaip ir 1961-2007 m. laikotarpiu. Skaičiuojant upių prietaką naudoti Nemuno hidrologinio modelio išvesties duomenys. Kritulių kiekis bei išgaravimas 2011-2100 m. skaičiuotas pagal tas pačias MS, kaip ir 1961-2007 m. laikotarpiu, tačiau naudojant ECHAM5 ir HadCM3 globalių klimato modelių išvesties duomenis pagal A2, A1B ir B1 šiltnamio dujų emisijų scenarijus. Išgaravimui apskaičiuoti taikytas Thornthwait metodas, naudojant oro temperatūros ir saulès šviesos duomenis. Tūrio pokytis (vandens apykaita Klaipèdos sąsiauriu) vertintas naudojant Kuršių marių vandens lygio duomenis ties Juodkrante, ìvedant pataisas pagal tris marių lygio kilimo scenarijus. Pagal pirmąji scenarijų marių lygis kyla $0,87 \mathrm{~mm} / \mathrm{m}$., pagal antrajj $-4,02 \mathrm{~mm} / \mathrm{m}$. ir pagal trečiajj $-4,65 \mathrm{~mm} / \mathrm{m}$.

\section{UPIŲ NUOTĖKIO IR JO EKSTREMALIŲ REIKŠMIŲ DAUGIAMETĖS KAITOS VERTINIMAS}

\section{Lietuvos upių metų ir sezonų nuotėkio kaitos trendai}

Mann-Kendall testas padejo analizuoti metų, sezonų ir nuosèkio periodų minimalius debitus [18]. Tyrimai buvo atlikti naudojant 1922$2003 \mathrm{~m}$. nuotèkio duomenis iš $32 \mathrm{VMS}$ (2 pav.).
2 pav. Lietuvos hidrologinès sritys, vandens matavimo ir meteorologijos stotys

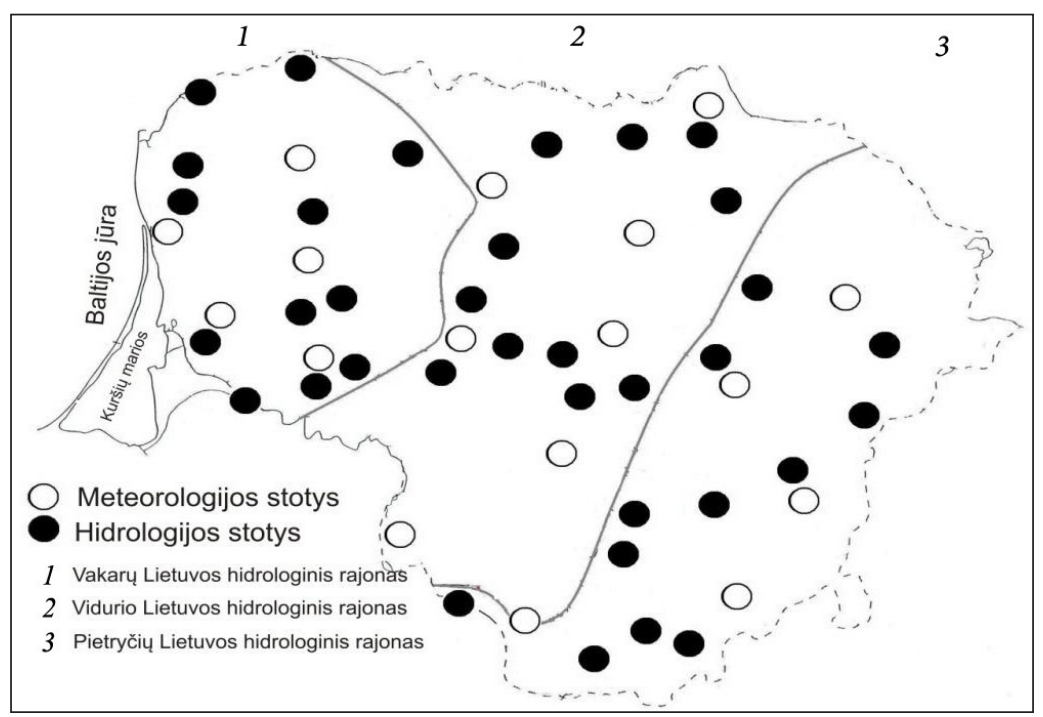


Tiriamasis laikotarpis suskirstytas $\mathfrak{i}$ tris dalis: 1922-2003, 1941-2003 ir 1961-2003 m. Tirtujų nuotèkio charakteristikų pagal Mann-Kendall testą nustatytų reikšmingų (5 \% reikšmingumo lygmuo) trendų sumine statistika pateikta 3 pav.

Iš 3 pav. matyti, kad analizuojant ilgiausią 1922-2003 m. laikotarpi reikšmingi neigiami trendai, t. y. nuotèkio mažejimas nustatytas metų, pavasario, vasaros ir rudens sezonais, o žiemos nuotèkis didèja. Dauguma VMS rodo pavasario maksimalių debitų $\left(Q_{\max }\right)$ mažèjimą ir ankstèjimą $\left(Q_{\text {data }}\right)$. Analizuojant 1941-2003 m. laikotarpi vyrauja tos pačios tendencijos. Nuotèkio pokyčiu trendai trumpiausiu 1961-2003 m. laikotarpiu rodo, kad išlieka ryški žiemos nuotèkio didejimo tendencija, pavasario nuotekio ir maksimalių debitų mažèjimo bei ankstejjimo tendencija. Per visą laikotarpi mažiausi pokyčiai yra būdingi rudens ir vasaros sezonams.

Tiek potvynių, tiek nuosèkiu eiga priklauso nuo vietovès klimato sąlygų, todèl jų analizè buvo atlikta atskiroms hidrologinems sritims - Vakarų, Vidurio ir Pietryčių, besiskiriančioms upių maitinimo pobūdžiu ir hidrologiniu režimu (2 pav.) [3].

Maksimalių debitų ir jų datų kaitos tendencijų analizè 29 pasirinktose upèse atlikta pagal Mann-Kendall testą trims laikotarpiams (19222012, 1941-2012, 1961-2012) [19]. Nustatyta vienareikšmiška maksimalių debitų datų kaitos ten- dencija visose trijose hidrologinėse srityse: pagal trijų skirtingų trukmių duomenų sekas potvynių maksimalūs debitai stebimi vis anksčiau, visoje Lietuvos teritorijoje nustatyti neigiami ir reikšmingai neigiami trendai. Maksimalių debitų dydžių kaitos tendencijos šiek tiek skirtingos (4 pav.). Vakarų Lietuvos upèse per du pirmuosius analizuojamuosius laikotarpius (1925-2012 ir 1941-2012 m.) trendų nebuvo arba buvo reikšmingai neigiami. Analizuojant 1961-2012 m. laikotarpio duomenis nustatyta, kad Vakarų Lietuvoje pagal daugumos VMS duomenis maksimalių potvynių kaitos trendai yra nereikšmingi. Vidurio ir Pietryčiu Lietuvos hidrologinėse srityse maksimalių debitu kaitos trendai per visus laikotarpius daugiausiai yra neigiami arba reikšmingai neigiami, tai reiškia, kad maksimalūs potvynio debitai mažèja.

Lietuvos upèse pasibaigus pavasario potvynio bangai, kai intensyvus debitų mažèjimas pereina i palyginti pastovius mažus debitus, prasideda gana ilgas nuosékio periodas, kuris baigiasi prasidejus rudeninèms liūtims. Tyrimams naudota viena svarbiausių nuosèkio laikotarpio charakteristikų - 30 sausiausių paeiliui einančių kalendorinių dienų vidutinis debitas $\left(Q_{30}\right)$.

Pagal ilgiausias duomenų sekas palyginus sausojo 30 d. laikotarpio pradžios datas iki $1960 \mathrm{~m}$. ir nuo $1961 \mathrm{~m}$. (nuo šio dešimtmečio klimatologai fiksuoja ryškias klimato kaitos tendencijas) nustatyta, kad îvyko esminis poslinkis iš birželio ị

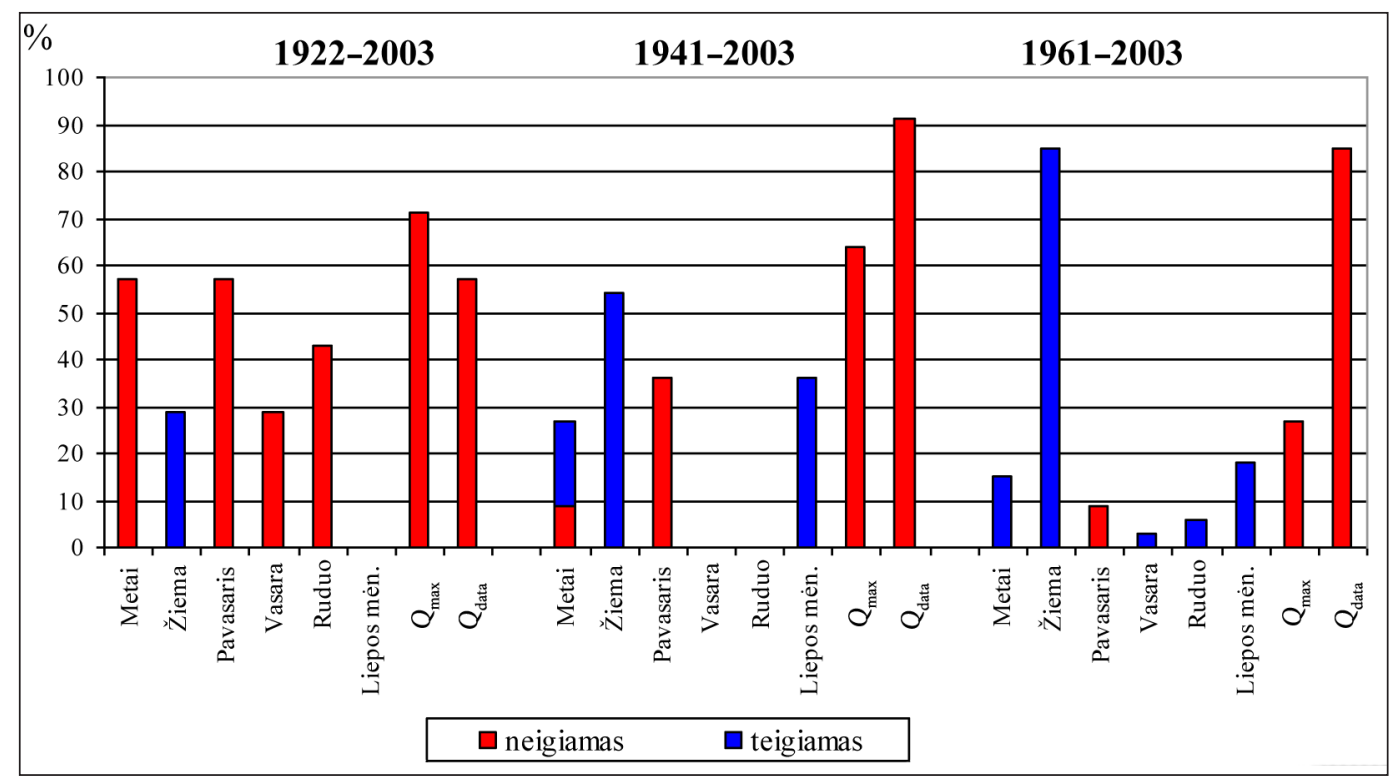

3 pav. Lietuvos upių metų ir sezonų nuotèkio reikšmingų trendų suminė (\%) statistika 


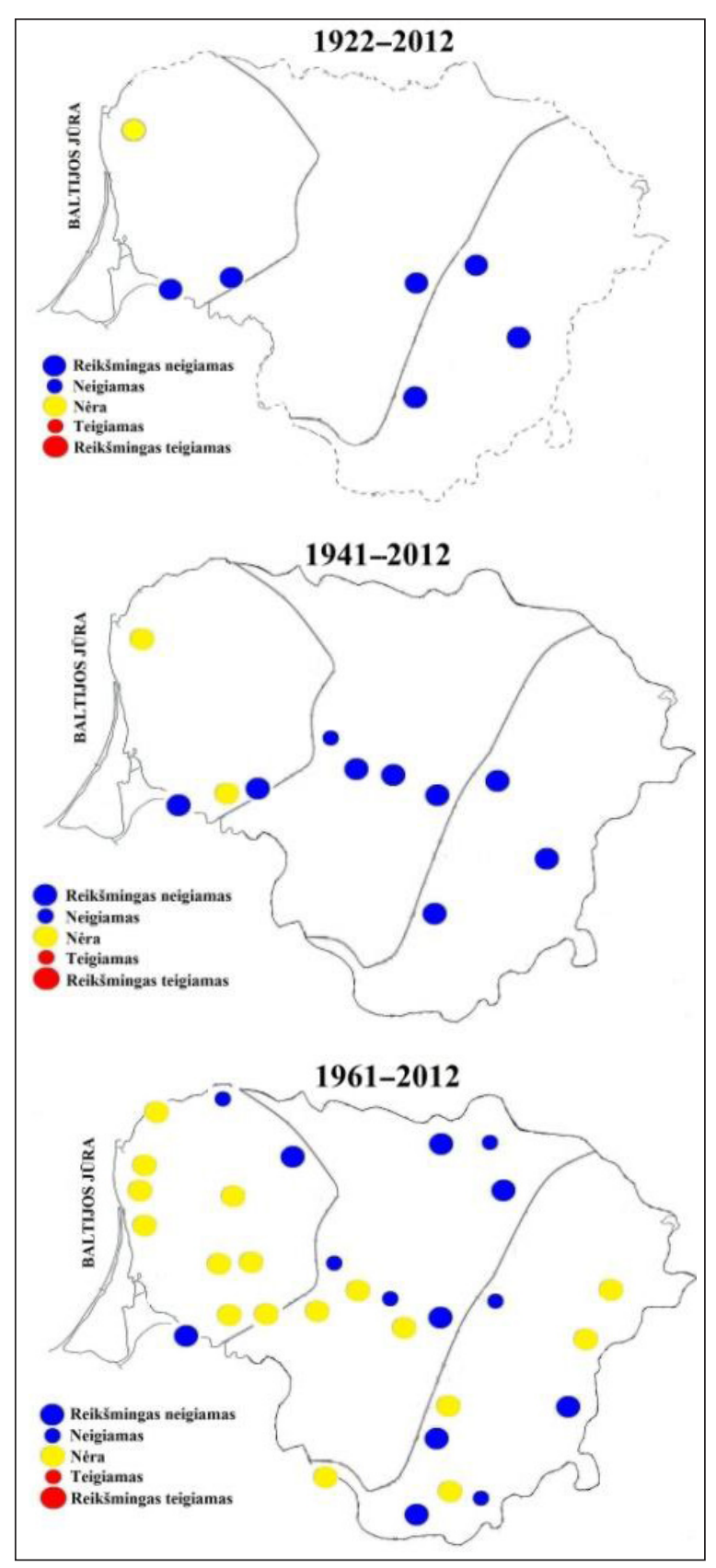

4 pav. Maksimalių debitų kaitos tendencijos Lietuvos teritorijoje

liepą ir rugpjūtį. Tai ypač būdinga Vakarų Lietuvos upèms.

Keturių pasirinktų laikotarpių Lietuvos upių sausiausio 30 parų laikotarpio nuotékio analizè pagal Mann-Kendall testą atlikta panaudojant 29 hidrologinių stočių duomenis. 1922-2012 m. laikotarpiu minimalus nuotekis analizuotas tik iš šešių hidrologijos stočių duomenų. Šiuo laikotarpiu Vidurio ir Pietryčių Lietuvoje trendų nenustatyta. Vakarų Lietuvoje, Minijos baseine, pastebètas tei- giamas trendas. Iš trumpesnio stebejjimų laikotarpio duomenų nustatyti reikšmingi teigiami trendai Nemuno baseine, tai reiškia, kad minimalus nuotèkis didejja.

\section{Upių nuotèkio ekstremalių reikšmių kaitos tikimybinè analizè}

Klimato pokyčių itaka upių potvynių debitams susijusi su ekstremalių verčių analize. Turima stebètų upès debitų eilutè suteikia informacijos apie konkretaus dydžio debito pasikartojimo empirinę tikimybę. Tais atvejais, kai reikia žinoti ekstremalių debitų pasikartojimo tikimybę, apie kuriuos stebèjimo duomenų nèra, atliekama ekstremalių verčių dažnumo analizè pasitelkiant teorinius tikimybinius skirstinius. Taip ekstrapoliuojamos debitu reikšmès, esančios už stebejimo duomenų ribų.

Pasirinktų 29 Lietuvos upių pavasario potvynio maksimalių ir nuosèkio minimalių debitų reikšmių tikimybinei analizei naudoti metodikoje aprašyti tikimybiniai skirstiniai. Trijų sričių upių potvynio maksimalių debitų eilutės buvo suskaidytos $\mathfrak{i}$ atskirus laikotarpius: 1961-1990 (klimato norma), 1961-2012 ir 1991-2012 m. (1 lentelè).

Potvynio duomenų eilučių tikimybinè analizè parodè, kad apibendrintųjų ekstremalių reikšmių skirstinys tinkamiausias empirinių pavasario potvynio duomenų dažnumo analizei visose hidrologinèse srityse (taip pat ir didžiosiose upèse) 1991-2012 m. laikotarpiu. Todèl prieiname prie išvados, kad reikšmingų klimato pokyčių laikotarpiu šis tikimybinis skirstinys yra labiausiai tinkamas Lietuvos upių potvynių dažnumui analizuoti ir pavasario maksimaliems debitams prognozuoti. Tikimybinių skirstinių nustatymas reikalingas potvynių dažnumo pokyčiams prognozuoti.

29 upių minimalių debitų duomenys buvo tiriami tais pačiais laikotarpiais kaip ir potvyniu maksimalūs debitai. Analizè parodè, kad upių nuosèkio debitų duomenys skirtingose hidrologinèse srityse tirtaisiais laikotarpiais atitiko labai panašius tikimybinius skirstinius. Pagal atitikimą stebejjimo duomenims (nuo geriausiai iki blogiausiai tinkančio) tirti tikimybiniai skirstiniai pasiskirste tokia tvarka: apibendrintųjų ekstremalių reikšmių, logaritminis Pirsono III tipo, trijų parametrų Gama, Veibulio, Gumbelio minimalios ekstremalios vertès. 
1 lentelè. Priskirtų tinkamumo rangų pasirinkto ilgio duomenų eilutėms apibendrinimo rezultatai* skirtingoms hidrologinèms sritims (h. s.) ir didžiosioms upėms (skirstinių pavadinimų trumpiniai pateikti metodikos skyrelyje)

\begin{tabular}{|c|c|c|c|c|c|c|c|c|c|c|}
\hline \multirow{2}{*}{ Laikotarpiai } & \multicolumn{5}{|c|}{ Vakarų Lietuvos h. s. } & \multicolumn{5}{|c|}{ Vidurio Lietuvos h. s. } \\
\hline & G3 & LP3 & GEV & W2 & EV1 & G3 & LP3 & GEV & W2 & EV1 \\
\hline $1961-1990$ & 26 & 19 & 17 & 34 & 39 & 26 & 14 & 11 & 22 & 32 \\
\hline $1961-2012$ & 24 & 17 & 16 & 40 & 38 & 23 & 11 & 15 & 27 & 29 \\
\hline $1991-2012$ & 22 & 13 & 11 & 33 & 26 & 8 & 4 & 2 & 9 & 7 \\
\hline \multirow{2}{*}{ Laikotarpiai } & \multicolumn{5}{|c|}{ Pietryčių Lietuvos h. s. } & \multicolumn{5}{|c|}{ Nemunas ir Neris } \\
\hline & G3 & LP3 & GEV & W2 & EV1 & G3 & LP3 & GEV & W2 & EV1 \\
\hline $1961-1990$ & 26 & 20 & 11 & 27 & 36 & 17 & 9 & 6 & 25 & 18 \\
\hline $1961-2012$ & 21 & 15 & 15 & 37 & 32 & 9 & 9 & 14 & 24 & 19 \\
\hline $1991-2012$ & 24 & 11 & 11 & 27 & 17 & 25 & 9 & 6 & 20 & 15 \\
\hline
\end{tabular}

"Kuo rangų suma mažesnè - tuo skirstinys tiksliau atkartoja stebejimo duomenų eilutes.

Pagal apibendrintųjų ekstremalių reikšmių tikimybinį skirstinị sudaryta Nemuno ties Smalininkais minimalių debitų pasiskirstymo tikimybinio tankio funkcija, kurios dèka galima prognozuoti įvairių tikimybių minimalius debitus (5 pav.).

\section{NEMUNO BASEINO UPIŲ NUOTÉKIO MODELIAVIMAS PAGAL SKIRTINGUS KLIMATO KAITOS SCENARIJUS}

Naudojant HBV modelị bei 1961-1990 m. laikotarpio nuotèkio, kritulių ir temperatūros duomenis, sukurtas Nemuno hidrologinis modelis [20].
Nemuno nuotèkis ties žiotimis sumodeliuotas iš Echam 5 bei HadCM3 modelių išvesties duomenų ir pagal A2, A1B ir B1 emisijų scenarijus (šeši klimato kaitos scenarijai) 2011-2100 m. laikotarpiu. Gauti rezultatai palyginti su foninio laikotarpio nuotèkiu (6 pav.).

Pirmuoju 2011-2040 m. laikotarpiu sumažès pavasario potvynių debitai, o dalis nuotekio iš pavasario persikels ị žiemos sezoną. Šiuo laikotarpiu prognozuojami du potvyniai: vienas žiemos pabaigoje, kitas pavasario viduryje. Žiemos laikotarpiu debitas vidutiniškai kis nuo $773 \mathrm{~m}^{3} / \mathrm{s}$ pagal Echam5 A1B scenarijų iki $1155 \mathrm{~m}^{3} / \mathrm{s}$ pagal HadCM3 A2 scenarijų ir vidutiniškai pagal

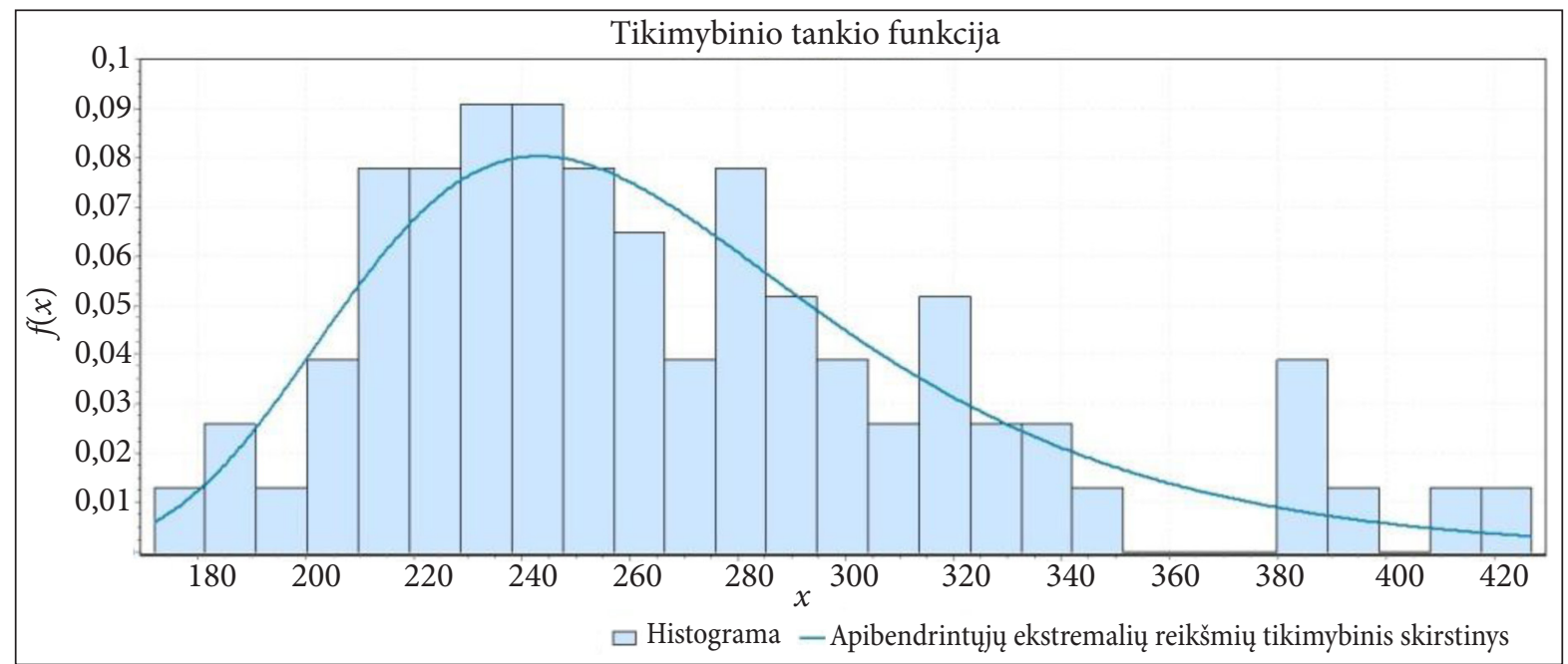

5 pav. Nemuno ties Smalininkais nuosèkio minimalių debitų pasiskirstymo tikimybinio tankio funkcija (histograma - stebejimo duomenys, kreive - apibendrintujų ekstremalių reikšmių tikimybinis skirstinys) 


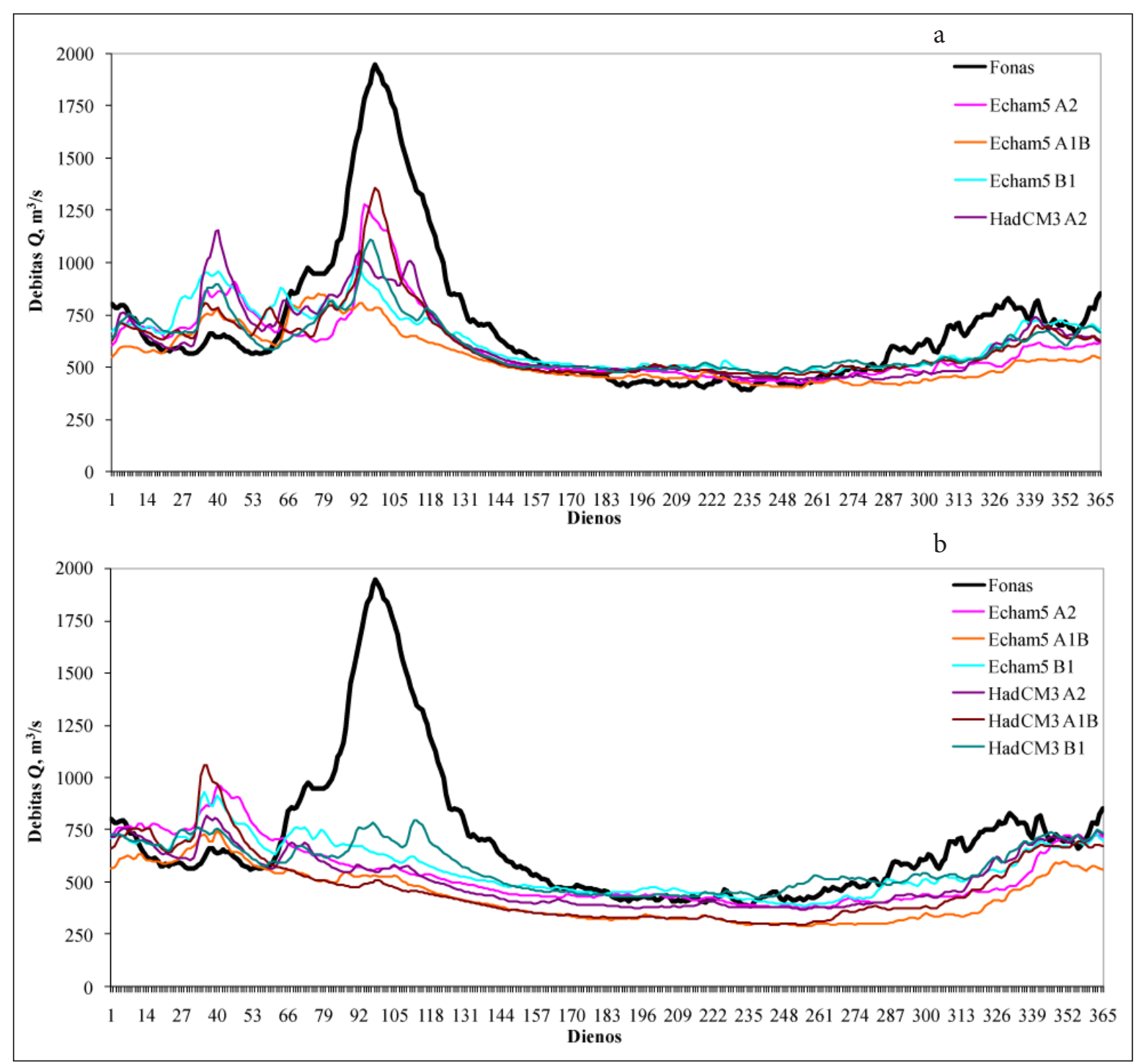

6 pav. Prognozuojamas Nemuno nuotekis ties žiotimis pagal Echam5 ir HadCM3 modelius bei A2, A1B ir B1 scenarijus 2011-2040 m. (a) ir 2071-2100 m. laikotarpiu (b)

6 scenarijus sieks $912 \mathrm{~m}^{3} / \mathrm{s}$. Pavasario potvynis bus didesnis: nuo $808 \mathrm{~m}^{3} / \mathrm{s}$ pagal Echam5 A1B iki $1355 \mathrm{~m}^{3} / \mathrm{s}$ pagal HadCM3 A1B ir vidutiniškai sieks $1097 \mathrm{~m}^{3} / \mathrm{s}$. Nustatyta, kad pavasario potvyniai gali būti didesni (iki $185 \mathrm{~m}^{3} / \mathrm{s}$ ) už žiemos potvynius, tačiau gerokai mažesni nei foniniu laikotarpiu (1946 m³/s). Vasaros sezono vidutinis prognozuojamas nuotèkis bus didesnis nuo $6 \mathrm{~m}^{3} / \mathrm{s}$ pagal Echam5 A1B scenarijų iki $57 \mathrm{~m}^{3} / \mathrm{s}$ pagal Echam5 A2 scenariju, palyginti su foniniu laikotarpiu. Rudens sezonu prognozuojamas vidutinis metinis nuotèkis bus mažesnis (nuo $48 \mathrm{~m}^{3} / \mathrm{s}$ pagal HadCM3 B1 scenarijų iki $136 \mathrm{~m}^{3} / \mathrm{s}$ pagal Echam5 A1B scenarijų), palyginti su foniniu laikotarpiu. Vidutinis meti- nis 2011-2040 m. laikotarpio debitas svyruoja nuo $541 \mathrm{~m}^{3} / \mathrm{s}$ pagal Echam5 A1B scenarijų iki $628 \mathrm{~m}^{3} / \mathrm{s}$ pagal Echam5 B1 scenariju ir vidutiniškai pagal 6 scenarijus yra $599 \mathrm{~m}^{3} / \mathrm{s}$. Tai net $96 \mathrm{~m}^{3} / \mathrm{s}$ (arba 13,8 \%) mažiau nei foniniu laikotarpiu $\left(695 \mathrm{~m}^{3} / \mathrm{s}\right)$.

2071-2100 m. laikotarpiu pavasario potvyniai persikels ị žiemos sezoną, o potvynių pikai sumažès perpus. Vidutinès didžiausios tokių potvynių reikšmès svyruos nuo $659 \mathrm{~m}^{3} / \mathrm{s}$ pagal Echam5 A2 scenarijų iki $1060 \mathrm{~m}^{3} / \mathrm{s}$ pagal HadCM3 A1B scenarijų. Vasaros sezonais vidutiniai metiniai debitai kis nuo $328 \mathrm{~m}^{3} / \mathrm{s} \mathrm{pa-}$ gal Echam5 A1B iki $451 \mathrm{~m}^{3} / \mathrm{s}$ pagal Echam5 A2 scenarijų. Vidutiniškai vasaros sezono debitas 
2071-2100 m. laikotarpiu bus $52 \mathrm{~m}^{3} / \mathrm{s}$ mažesnis negu foninio laikotarpio debitas. Rudens sezono nuotèkis gerokai sumažès ir jo sklaida bus didesnè. Mažiausias rudens sezono debitas prognozuojamas pagal Echam5 A1B scenarijų $-331 \mathrm{~m}^{3} / \mathrm{s}$ ir didžiausias pagal HadCM3 B1 scenarijų - $526 \mathrm{~m}^{3} / \mathrm{s}$. Vidutiniškai pagal 6 scenarijus prognozuojamas $430 \mathrm{~m}^{3} / \mathrm{s}$ debitas, kuris yra $142 \mathrm{~m}^{3} / \mathrm{s}$ mažesnis negu foninio laikotarpio debitas. Metinis šio laikotarpio debitas svyruos nuo $434 \mathrm{~m}^{3} / \mathrm{s}$ pagal Echam5 A1B scenarijų iki $575 \mathrm{~m}^{3} / \mathrm{s}$ pagal HadCM3 B1 scenarijų. Pagal visus 6 scenarijus vidutinis metinis $2071-2100 \mathrm{~m}$. laikotarpio debitas bus $517 \mathrm{~m}^{3} / \mathrm{s}$, t. y. $178 \mathrm{~m}^{3} / \mathrm{s}$ (arba 25,6 \%) mažesnis už foninio laikotarpio debitą.

\section{KURŠIŲ MARIŲ VANDENS BALANSO IR JO ELEMENTŲ KAITOS ANALIZE்}

Upių prietaka sudaro didžiąją Kuršių marių vandens balanso pajamų dali, todèl labai svarbu ją tiksliai ịvertinti. Tiriamojo 1961-2007 m. laikotarpio upių prietaka apskaičiuota paros intervalu, naudojant tiesioginių matavimų duomenis ir taikant analogijos metodus (7 pav.) [20].

1961-2007 m. laikotarpio vidutinè metinè upių prietaka yra $21,774 \mathrm{~km}^{3}$ ir svyravo nuo 13,967 km³ (1969 m.) iki 30,041 km³ (1980 m.) (7 pav.). Pritaikius Mann-Kendall testą gauta, kad iki $1982 \mathrm{~m}$. upių prietakos ị marias trendas yra teigiamai reikšmingas (patikimumas $95 \%$ ), o nuo 1983 m. prietaka mažèja, tačiau mažèjimas statistiškai nereikšmingas. Nežymiai mažejant nuotekiui, pastebimai keičiasi jo metinis pasiskirstymas. Nuotékio pasiskirstymas metais analizuotas suskirsčius tiriamajj laikotarpi i 4 dalis po 12 metu (1961-1972, 1973-1984, 1985-1996 ir 1997-2007 m.). Tiriamaisiais keturiais laikotarpiais vasaros nuotèkis sudarè nuo 15,5 iki 16,7 \% metų nuotèkio. Metinio nuotékio dalis gerokai keitèsi rudeni - svyravo nuo 18,9 iki 22,1\%. Didžiausi pokyčiai įvyko nuotèkiui pasiskirstant žiemą ir pavasari. Palyginus 1961-1972 ir 19972007 m. laikotarpių žiemos bei pavasario sezonais i marias patekusio suminio upių nuotekio dalis, nustatytas esminis nuotèkio persiskirstymas: 1961-1972 m. laikotarpiu skirtumas tarp pavasario ir žiemos siekè $24 \%$ (žiemą 20,8 \%, pavasari 44,8 \%), o 1997-2007 m. laikotarpiu - tik 4,2\% (žiemą 29,9 \%, o pavasarị 34,1\%). Toks daugiamečio suminio upių nuotèkio ì Kuršių marias pasiskirstymo pokytis leidžia daryti išvadą, kad pavasario potvyniai ankstejja, maksimalūs debitai fiksuojami vis anksčiau ir jų reikšmès mažèja.

Apskaičiuojant kritulius ir išgaravimą Kuršių marių plotas vertintas kaip kintamas parametras, priklausantis nuo vidutinio mariu vandens lygio. 1961-2007 m. laikotarpiu vidutinis metinis kritulių kiekis buvo $1,199 \mathrm{~km}^{3} / \mathrm{m}$., o vidutinis metinis išgaravimas nuo marių paviršiaus $-1,008 \mathrm{~km}^{3} / \mathrm{m}$.

Vidutinis daugiametis nuotèkis iš Kuršių marių ỉ Baltijos jūrą $\left(Q_{M}\right)$ (8a pav.) tirtuoju

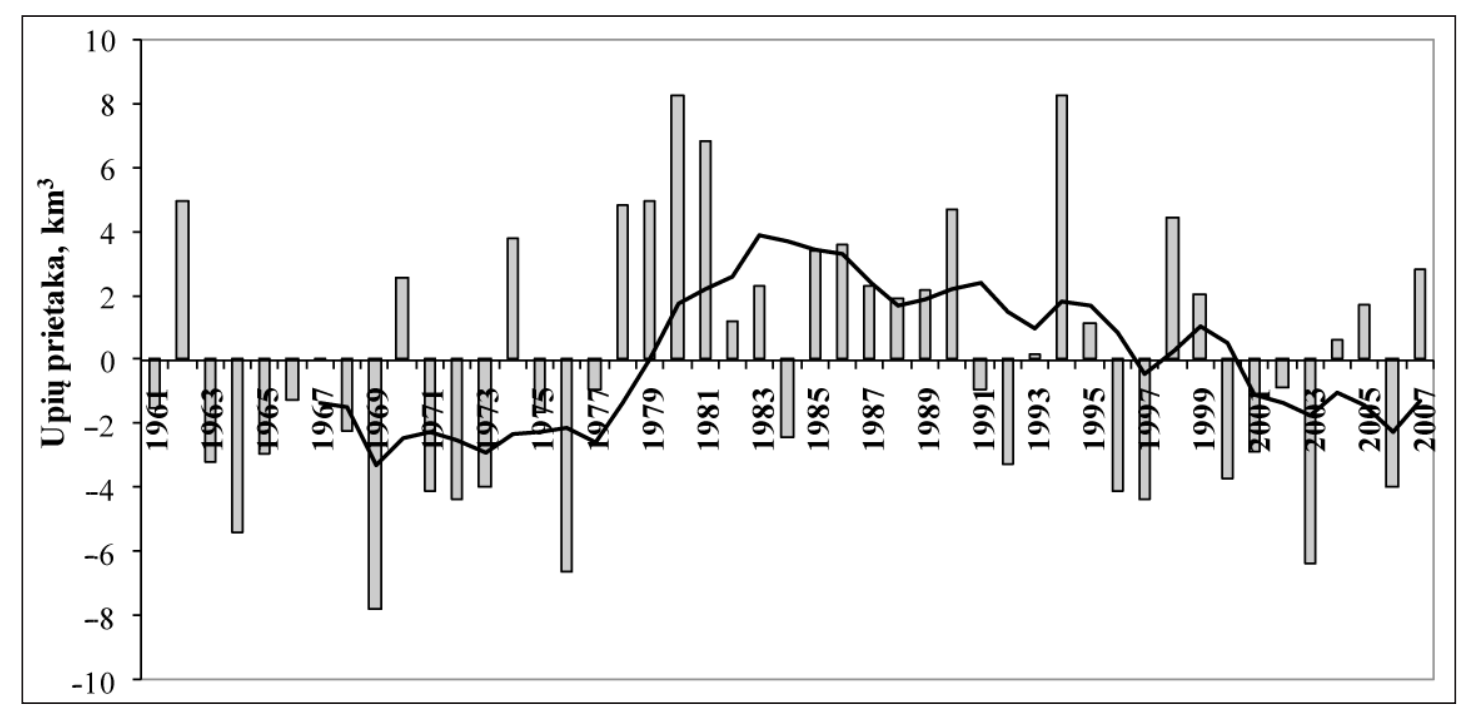

7 pav. Metinės upių prietakos j̨ Kuršių marias pokyčiai 1961-2007 m. (lyginant su 1961-2007 m. vidurkiu) 


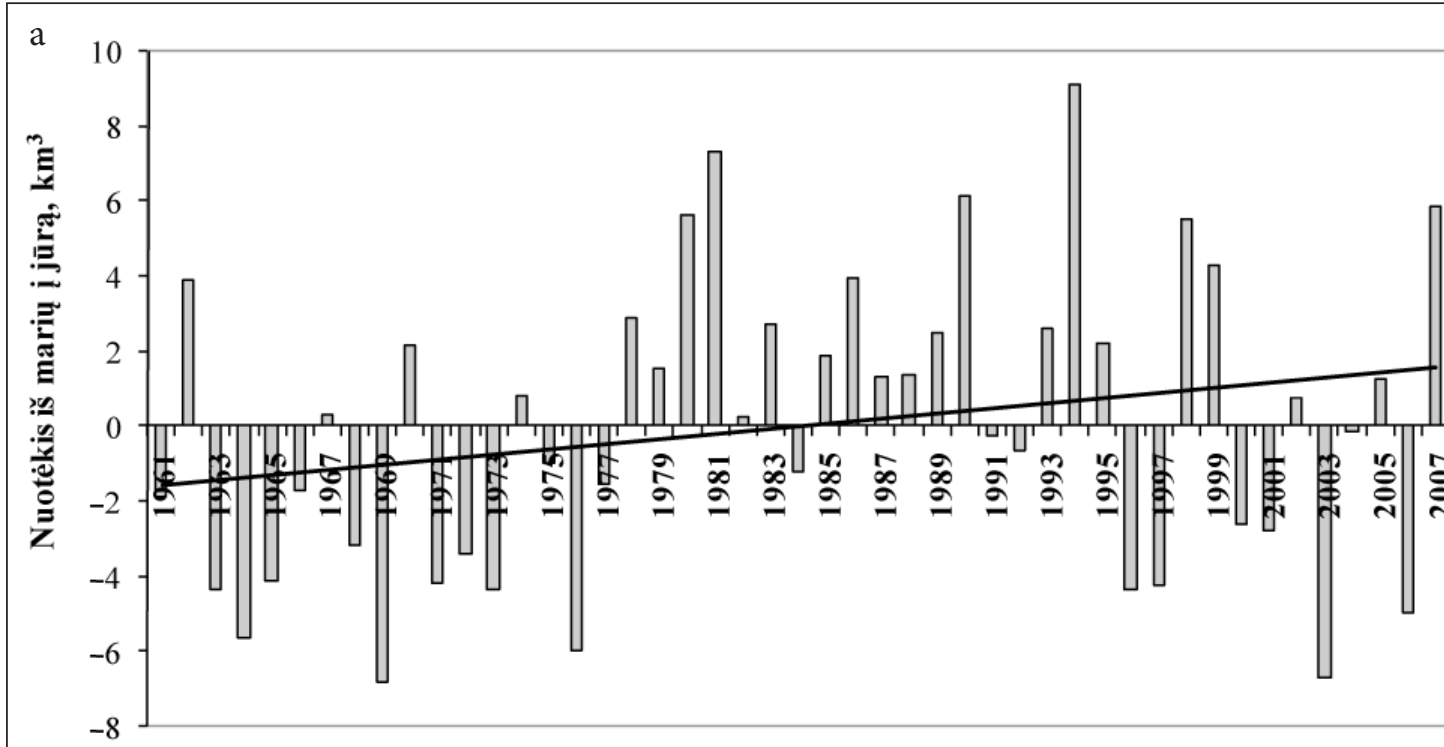

$\mathrm{b}$

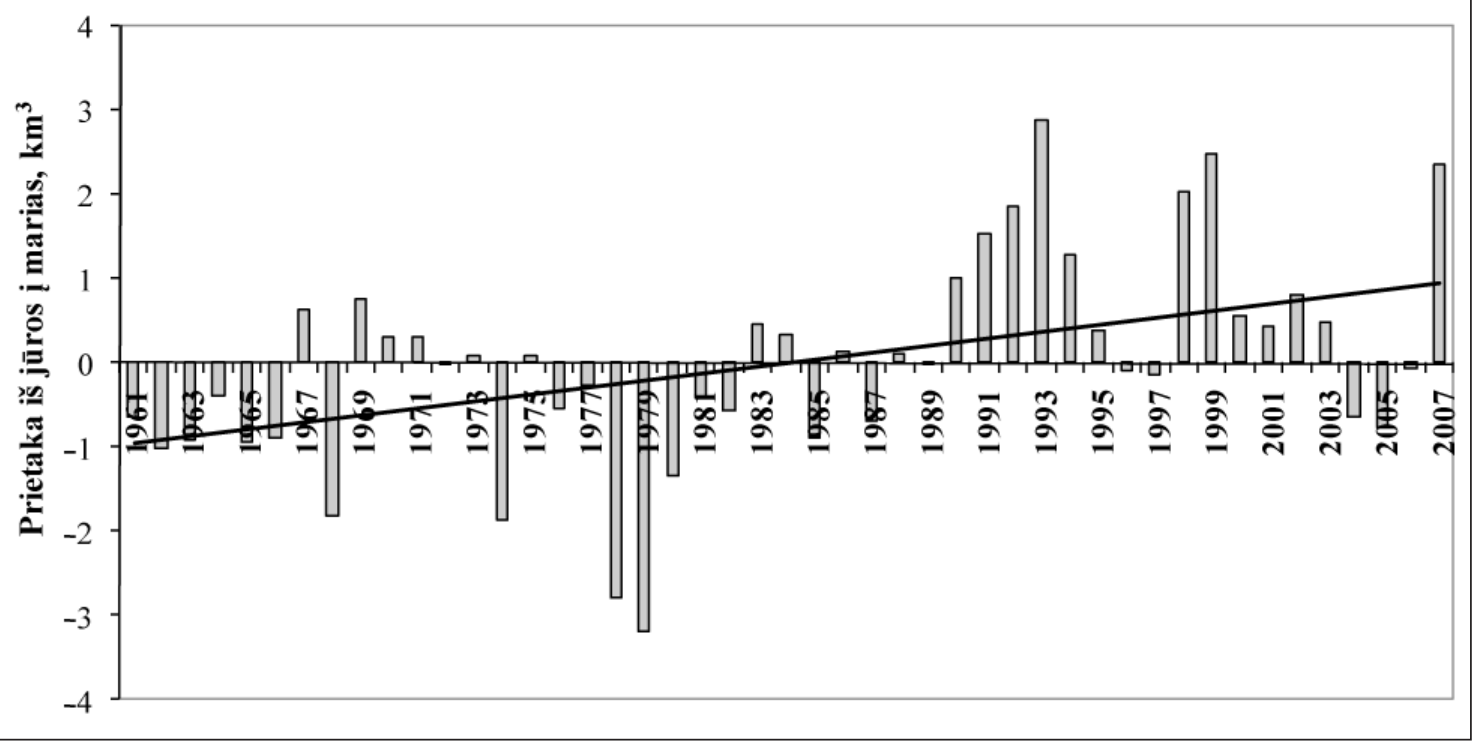

8 pav. Daugiametės apykaitos Klaipèdos sąsiauriu pokyčiai, palyginti su 1961-2007 m. vidurkiu: a) nuotėkio iš Kuršių marių i Baltijos jūrą $\left(Q_{M}\right)$ pokyčiai, b) prietakos iš Baltijos jūros į Kuršių marias $\left(Q_{\jmath}\right)$ pokyčiai

laikotarpiu siekè $27,630 \mathrm{~km}^{3}$, o vidutinè daugiametė prietaka iš Baltijos jūros ị Kuršių marias $\left(Q_{J}\right)-6,167 \mathrm{~km}^{3}$ (8b pav.).

Gilinant Klaipèdos sąsiaurị keičiasi jo pralaidumas. Aktualu žinoti, kaip tiriamuoju laikotarpiu keitèsi $Q_{M}$ ir $Q_{p}$ ar jų kaita yra susijusi tik su sąsiaurio gilinimu, ar ir su gamtiniais pokyčiais, t. y. klimato kaita. 1961-2007 m. laikotarpio nuotèkis iš Kuršių marių i̇ Baltijos jūrą $\left(Q_{M}\right)$ tirtas atsižvelgiant i 1981-1982 m. Klaipedos uosto padalijimą í dvi dalis - iki $1982 \mathrm{~m}$. ir nuo $1983 \mathrm{~m}$. Pritaikius Mann-Kendall testą nustatyta, kad iki 1982 m. nuotèkio iš marių ì jūrą trendas yra teigiamai reikšmingas, o nuo $1983 \mathrm{~m}$. stebimas nežymus mažejjimas. Analizuojant daugiametę prietaką iš Baltijos jūros ị Kuršių marias $\left(Q_{J}\right)$ nustatyta, kad nuo $1983 \mathrm{~m}$. prietaka dideja (8b pav.). $Q_{J}$ didèjimą pastaraisiais dešimtmečiais lëmè tiek uosto plètra (akvatorijos gilinimas), tiek klimato kaita. Ivertinus atskirų vandens balanso elementų suminę apskaičiavimo paklaidą nustatyta, kad 1961-2007 m. laikotarpio vandens balansas apskaičiuotas pakankamu tikslumu. Suminis vandens balansas pateiktas 2 lentelèje. 
2 lentelè. 1961-2007 m. laikotarpio Kuršių marių vandens balansas ( $\left.\mathrm{km}^{3}\right)$

\begin{tabular}{|c|c|c|c|c|c|c|c|c|c|c|c|c|c|}
\hline \multirow{2}{*}{$\begin{array}{c}\text { Balanso } \\
\text { komponentai }\end{array}$} & \multicolumn{12}{|c|}{ Mènesiai } & \multirow{2}{*}{$\begin{array}{l}\text { Per } \\
\text { metus }\end{array}$} \\
\hline & I & II & III & IV & V & VI & VII & VIII & IX & $X$ & XI & XII & \\
\hline Upių prietaka $\left(Q_{U}\right)$ & 1,969 & 1,783 & 2,803 & 3,607 & 1,873 & 1,234 & 1,140 & 1,108 & 1,120 & 1,423 & 1,808 & 1,905 & 21,774 \\
\hline $\begin{array}{l}\text { Prietaka iš jūros i } \\
\text { marias }\left(Q_{j}\right)\end{array}$ & 0,478 & 0,327 & 0,293 & 0,246 & 0,320 & 0,476 & 0,504 & 0,547 & 0,667 & 0,758 & 0,898 & 0,654 & 6,167 \\
\hline Krituliai $(P)$ & 0,087 & 0,062 & 0,065 & 0,059 & 0,067 & 0,095 & 0,118 & 0,133 & 0,131 & 0,137 & 0,132 & 0,107 & 1,194 \\
\hline Pajamos & 2,534 & 2,172 & 3,161 & 3,912 & 2,260 & 1,805 & 1,762 & 1,788 & 1,918 & 2,318 & 2,838 & 2,666 & 29,135 \\
\hline
\end{tabular}

\begin{tabular}{|c|c|c|c|c|c|c|c|c|c|c|c|c|c|}
\hline $\begin{array}{l}\text { Nuotèkis iš marių i } \\
\text { jūrą }\left(Q_{M}\right)\end{array}$ & 2,472 & 2,283 & 2,985 & 3,947 & 2,321 & 1,543 & 1,531 & 1,652 & 1,733 & 2,133 & 2,529 & 2,501 & 27,630 \\
\hline Išgaravimas (Z) & 0,023 & 0,020 & 0,030 & 0,055 & 0,115 & 0,155 & 0,174 & 0,163 & 0,119 & 0,073 & 0,048 & 0,032 & 1,008 \\
\hline Išlaidos & 2,495 & 2,303 & 3,015 & 4,002 & 2,436 & 1,698 & 1,705 & 1,815 & 1,852 & 2,206 & 2,577 & 2,533 & 28,638 \\
\hline Tūrio pokytis & $-0,002$ & $-0,012$ & $-0,046$ & 0,030 & 0,083 & 0,024 & $-0,024$ & $-0,016$ & $-0,025$ & 0,026 & $-0,050$ & 0,056 & 0,045 \\
\hline Nedermè & 0,041 & $-0,119$ & 0,192 & $-0,060$ & $-0,259$ & 0,083 & 0,081 & $-0,011$ & 0,091 & 0,086 & 0,311 & 0,077 & 0,452 \\
\hline
\end{tabular}

\section{Kuršių marių vandens balanso elementų prognozė pagal ịvairius klimato kaitos scenarijus XXI a.}

Kuršių marių vandens balansas XXI a. skaičiuotas trims laikotarpiams (2011-2040, 2041-2070 ir 2071-2100 m.). Atskiri vandens balanso elementai - upių prietaka, krituliai bei išgaravimas - imti kaip 6 klimato kaitos scenarijų vidurkis (du klimato kaitos modeliai - Echam5, HadCM3 ir trys emisiju scenarijai - A2, A1B ir B1) iš tam tikro trisdešimtmečio.

Svarbiausią vandens balanso pajamų dalị sudaro upių prietaka. Foniniu, t. y. 1961-1990 m. laikotarpiu, ji vidutiniškai siekè 22,084 km³/ metus. Pagal modeliavimo rezultatus nustatyta, kad prietaka mažès ir pagal šešių scenarijų vidurkị 2011-2040 m. ji sieks 18,886 km³/metus, 2041-2070 m. - 17,372 km $/$ metus ir 2071$2100 \mathrm{~m} .-16,236 \mathrm{~km}^{3} /$ metus.

Mažiausią Kuršių marių vandens balanso dalị sudaro krituliai, priskiriami prie pajamų, ir išgaravimas, priskiriamas prie išlaidų. Šie du vandens balanso komponentai kompensuoja vienas kitą, nes yra priešingų ženklų. Jų metinę kaitą lemia klimatas. Išgaravimas yra glaudžiai susijęs su oro temperatūra ir vejjo greičiu analizuojamoje teritorijoje. Krituliai sudaro pačią mažiausią vandens balanso pajamų dalị. Foniniu 1961-
1990 m. laikotarpiu per metus ị Kuršių marias vidutiniškai iškrisdavo $1,157 \mathrm{~km}^{3} /$ metus kritulių. 2011-2040 m. laikotarpiu i marias vidutiniškai iškris $1,155 \mathrm{~km}^{3} /$ metus, 2041-2070 m. - 1,172 $\mathrm{km}^{3} /$ metus ir $2071-2100 \mathrm{~m}$. - $1,201 \mathrm{~km}^{3} / \mathrm{me}-$ tus kritulių. Foniniu laikotarpiu vidutiniškai per metus išgaruodavo $1,052 \mathrm{~km}^{3}$. Tuo tarpu 2011-2040 m. iš marių išgaruos $1,075 \mathrm{~km}^{3}$, 2041-2070 m. - 1,152 km $\mathrm{km}^{3}$ ir 2071-2100 m. vidutiniškai $1,228 \mathrm{~km}^{3}$ per metus.

Apykaita per Klaipèdos sąsiauri yra sunkiausiai išmatuojamas vandens balanso komponentas, todèl jis apskaičiuotas taikant vandens balanso lygtí, kaip ir 1961-2009 m. laikotarpiu. Vandens apykaita per Klaipedos sąsiauri skaičiuota laikantis trijų vandens lygio kilimo scenariju - (1) $0,87 \mathrm{~mm} / \mathrm{m}$; (2) $4,02 \mathrm{~mm} / \mathrm{m}$; (3) $4,65 \mathrm{~mm} / \mathrm{m}$. Gauta, kad nuotèkis iš Kuršių marių ì Baltijos jūrą 2010-2040 m. gali sumažèti iki $24,963 \mathrm{~km}^{3}$ per metus, $2041-2071 \mathrm{~m}$. - iki 23,942 $\mathrm{km}^{3}$ per metus, o 2071-2100 m. - iki $23,495 \mathrm{~km}^{3}$ per metus. Tuo tarpu druskingo vandens prietaka iš Baltijos jūros i Kuršių marias gali padidèti atitinkamai iki 6,356; 6,871 ir $7,490 \mathrm{~km}^{3}$ per metus.

3 lenteleje pateikti trys galimi Kuršių marių vandens balansai pagal tris skirtingus jūros lygio kilimo scenarijus. 
3 lentelè. Kuršių marių vandens balansai (km³) 1961-1990, 1960-2009, 2011-2040, 2041-2070 ir 2071-2100 m. laikotarpiais

\begin{tabular}{|c|c|c|c|c|c|c|c|c|c|}
\hline $\begin{array}{l}\text { Jūros lygio kai- } \\
\text { tos scenarijus }\end{array}$ & Laikotarpis & $Q_{u}$ & $Q_{m}$ & $Q_{j}$ & $P$ & $Z$ & $\Delta V$ & Paklaida & $\begin{array}{c}\text { Didžiausia } \\
\text { leistina } \\
\text { paklaida }\end{array}$ \\
\hline & 1961-1990 & 22,084 & 27,467 & 5,658 & 1,157 & 1,052 & 0,018 & 0,380 & 1,123 \\
\hline & 1960-2009 & 21,784 & 27,642 & 6,171 & 1,199 & 1,007 & 0,037 & 0,468 & 0,810 \\
\hline \multirow{3}{*}{ (1) } & $2011-2040$ & 18,883 & 24,870 & 6,239 & 1,155 & 1,075 & 0,015 & 0,317 & 0,562 \\
\hline & $2041-2070$ & 17,372 & 23,625 & 6,527 & 1,172 & 1,152 & 0,016 & 0,277 & 0,590 \\
\hline & $2071-2100$ & 16,236 & 22,915 & 6,855 & 1,201 & 1,228 & 0,019 & 0,130 & 0,665 \\
\hline \multirow{3}{*}{ (2) } & 2011-2040 & 18,883 & 24,996 & 6,399 & 1,155 & 1,075 & 0,015 & 0,351 & 0,572 \\
\hline & 2041-2070 & 17,372 & 24,042 & 6,972 & 1,172 & 1,152 & 0,012 & 0,309 & 0,632 \\
\hline & $2071-2100$ & 16,236 & 23,708 & 7,708 & 1,201 & 1,228 & 0,018 & 0,190 & 0,699 \\
\hline \multirow{3}{*}{ (3) } & 2011-2040 & 18,883 & 25,022 & 6,429 & 1,155 & 1,075 & 0,014 & 0,355 & 0,572 \\
\hline & $2041-2070$ & 17,372 & 24,160 & 7,113 & 1,172 & 1,152 & 0,016 & 0,328 & 0,607 \\
\hline & $2071-2100$ & 16,236 & 23,863 & 7,907 & 1,201 & 1,228 & 0,015 & 0,238 & 0,714 \\
\hline
\end{tabular}

\section{IŠVADOS}

1. Metų ir sezonų upių nuotèkio trendų analizè parodè, kad ryškiausi nuotèkio didejjimo pokyčiai vyksta žiemos sezono metu ir kai mažèja pavasario nuotèkis, o mažiausi pokyčiai būdingi vasaros ir rudens sezonams.

2. Vakarų Lietuvoje maksimalių potvynių kaitos trendų nenustatyta arba jie yra nereikšmingi, o Vidurio ir Pietryčiu Lietuvos hidrologinèse srityse maksimalių debitu kaitos trendai per visus laikotarpius daugiausia yra neigiami arba reikšmingai neigiami, tai reiškia, kad maksimalūs potvynio debitai mažèja. Reikšmingų trendų upių nuosékio debitų eilutėse nenustatyta. Apibendrintųjų ekstremalių reikšmių skirstinys yra tinkamiausias empirinių nuotèkio ekstremalių verčių dažnumui analizuoti visų trijų hidrologinių sričių Lietuvos upèms.

3. Prognozuotas Nemuno baseino upių nuotèkis XXI a. Didžiausias Nemuno nuotèkis ties žiotimis prognozuotas pagal B1 scenarijų, o mažiausias - pagal A1B scenarijų. Per XXI a. Nemuno nuotekis ties žiotimis pagal 6 klimato kaitos scenarijus, palyginti su 1961-1990 m. laikotarpiu, vidutiniškai didės žiemos sezonu (4,1\%), o pavasario, vasaros, rudens sezonais bei metinis nuotekis mažès (atitinkamai 42,1, 1,7, 19,6 ir 19,8 \%). Prognozuojant nuotèki pastebèta, kad prietakos kaitą invairiais laikotarpiais lemia ne tik emisijų scenarijai, bet ir pasirinktas globalinis klimato modelis.
4. Apskaičiuotas Kuršių marių vandens balansas 1961-2007 m. laikotarpiu. Suminè upių prietaka ị Kuršių marias yra $21,774 \mathrm{~km}^{3}$ per metus, krituliai $-1,194 \mathrm{~km}^{3}$ per metus, išgaravimas $-1,008 \mathrm{~km}^{3}$ per metus. Druskingo vandens prietaka iš Baltijos jūros ị Kuršių marias siekia $6,167 \mathrm{~km}^{3}$ per metus ir gèlo vandens nuotèkis iš Kuršių marių i Baltijos jūrą - 27,630 km³ per metus. Iki $1982 \mathrm{~m}$. prietaka iš Baltijos jūros i Kuršių marias nežymiai mažèjo, o nuo 1983 m. - didejja. Prietakos iš Baltijos jūros ¡ Kuršiu marias didejimas sietinas su klimato kaita ir Klaipèdos uosto plètra.

5. Kuršių marių vandens balanso pokyčiai XXI a. prognozuoti atsižvelgus tik i klimato kaitos scenarijus. Nustatyta, kad, palyginti su foniniu laikotarpiu, upių prietaka sumažès $26 \%$, dèl kylančios oro temperatūros išgaravimas didès $25 \%$, kritulių kiekis didès nežymiai (4 \%), nuotekis iš Kuršių marių ì Baltijos jūrą sumažès 17 \%, o prietaka iš Baltijos jūros į Kuršių marias padidès $39 \%$.

Gauta 20160630 Priimta 20160714

\section{Literatūra}

1. Jablonskis J., Lasinskas M. Lietuvos TSR upiu kadastras (debitai, nuolydžiai, galingumai). T. 3. Vilnius, $1962.640 \mathrm{p}$.

2. Lasinskas M. Lietuvos upiu nuotèkio tyrimai. Kaunas: Lietuvos energetikos institutas, 1994. $151 \mathrm{p}$. 
3. Gailiušis B., Jablonskis J., Kovalenkovienė M. Lietuvos upes. Hidrografija ir nuotékis. Kaunas: Lietuvos energetikos institutas, 2001. 791 p.

4. Gailiušis B., Kriaučiūnienè J., Rimavičiūtė E. Modelling the effect of the hydroelectric pumped storage plant on hydrodynamic regime of the Kaunas Reservoir in Lithuania. Nordic Hydrology. 2003. Vol. 34. Iss. 5. P. 507-518.

5. Reihan A., Koltsova T., Kriaučiūnienè J., Lizuma L., Meilutytè- Barauskienè D. Changes in water discharges of the Baltic States rivers in the 20th century and its relation to climate change. Nordic Hydrology. 2007. Vol. 38. No. 4-5. P. 401-412.

6. Kriaučiūnienė J., Meilutytè-Barauskienè D., Rimkus E., Kažys J., Vincevičius A. Climate change impact on hydrological processes in Lithuanian Nemunas river basin. Baltica. 2008. Vol. 21. No. 1-2. P. 51-61.

7. Kriaučiūnienė J., Meilutytė-Barauskienė D., Reihan A., Koltsova T., Lizuma L., Šarauskienè D. Variability in temperature, precipitation and river discharge in Baltic States. Boreal Environment Research. 2012. Vol. 17. P. 150-162.

8. Reihan A., Kriaučiūnienè J., Meilutyte-Barauskienè D., Kolcova T. Temporal variation of spring flood in rivers of the Baltic States. Hydrology Research. 2012. Vol. 43. No. 4. P. 301-314.

9. Jakimavičius D., Kriaučiūnienè J. The climate change impact on the water balance of the $\mathrm{Cu}$ ronian Lagoon. Water Resources. 2013. Vol. 40. No. 2. P. 120-132.

10. Kriaučiūnienė J., Jakimavičius D., Šarauskienė D., Kaliatka T. Estimation of uncertainty sources in the projections of Lithuanian river runoff. Stochastic Environmental Research and Risk Assessment. 2013. Vol. 27. No. 4. P. 769-784.

11. Hall J., Arheimer B., Borga M., Brazdil R., Claps P., Kiss A., Kjeldsen T. R., Kriaučiūnienė J.,
Kundzewicz Z. W., Lang M., Llasat M. C., Macdonald N., McIntyre N., Mediero L., Merz B., Merz R., Molnar P., Montanari A., Neuhold C., Parajka J., Perdigao R. A. P., Plavcova L., Rogger M., Salinas J. L., Sauquet E., Schar C., Szolgay J., Viglione A., Bloschl G. Understanding flood regime changes in Europe: a state of-theart assessment. Hydrology and Earth System Sciences. 2014. Vol. 18. P. 2735-2772.

13. Šarauskienė D., Kriaučiūnienė J., Reihan A., Klavis M. Flood pattern changes in the rivers of the Baltic countries. Journal of Environmental Engineering and Landscape Management. 2015. Vol. 23. Iss. 2. P. 28-38.

13. Maidment D. R. Handbook of Hydrology. McGraw-Hill Inc., New York, 1993. 1424 p.

14. Integrated Hydrological Modelling System. 2005. Manual. Version 5.8. SMHI.

15. World Meteorological Organization. The Role of Climatological Normals in a Changing Climate. 2007. WCDMP-No. 61, WMO-TD/No. 1377, Geneva.

16. Balany F. Different ways of calculating catchment rainfall: case in Indonesia. Civil Engineering Forum. 2011. Vol. XX/1 - September. P. 1175-1182.

17. Červinskas E. Nauji Kuršių marių ploto matavimai. Lietuvos TSR aukštujų mokyklu mokslo darbai. Geografija ir geologija. 1972. T. IX. P. 45-53.

18. Klimato kaitos įtaka Lietuvos vandens ištekliu būklei ir hidroenergetikos sektoriui: biudžetinè ataskaita, 2007-2009 m.

19. Lietuvos upių ekstremalių hidrologinių reiškinių tyrimai: biudžetinè ataskaita, 2013-2015 m.

20. Kuršiu mariu hidrologinio režimo pokyčiu dèl gamtiniu ir antropogeniniu veiksniu tyrimai: biudžetinè ataskaita, 2010-2012 m. 
Jūratė Kriaučiūnienė, Brunonas Gailiušis, Diana Šarauskienė, Darius Jakimavičius,

Aldona Jurgelènaitè, Diana Meilutytè-Lukauskienè, Vytautas Akstinas, Aldona Tomkevičienė, Valdas Irbinskas

\section{STUDIES OF CLIMATE CHANGE IMPACT ON LITHUANIAN WATER RESOURCES}

\section{Summary}

In 1957, the Laboratory of Hydrology under the leadership of the famous Lithuanian hydrologist professor Lasinskas began an extensive research of Lithuanian water bodies. A large number of different studies have been performed, important monographs have been published. In the last decades, the main research objects of the laboratory have remained the same; however, the research topics change, much longer datasets of hydrological data are available, and the modern research methods are applied. The article presents the contribution of the Laboratory of Hydrology (of Lithuanian Energy Institute) to the development of hydrology science; the most significant studies of the last decade related to climate change impact on Lithuanian water resources (rivers and the Curonian Lagoon) are described. An analysis of Lithuanian river runoff and the Curonian Lagoon water balance in the past was performed. Statistical methods helped identifying the changes of river runoff and its extreme values that already occurred. The prognosis of the river runoff in the Nemunas Basin area (that covers 75\% of the Lithuanian territory) was accomplished applying the hydrological model HBV and using two global climate models (Echam5 and HadCM3) and three emission scenarios (A2, A1B, B1). The changes of the Curonian Lagoon water balance in the 21st century were assessed.

Keywords: climate change, rivers, Curonian Lagoon, statistical methods, hydrologic modelling 